This is a self-archived version of an original article. This version may differ from the original in pagination and typographic details.

Author(s): Potinkara, Nika

Title: Categories and boundaries in Sámi exhibitions

Year: 2020

Version: Accepted version (Final draft)

Copyright: (c) 2020 Informa UK Limited

Rights: In Copyright

Rights url: http://rightsstatements.org/page/InC/1.0/?language=en

Please cite the original version:

Potinkara, N. (2020). Categories and boundaries in Sámi exhibitions. Ethnic and Racial Studies, 43(12), 2140-2157. https://doi.org/10.1080/01419870.2019.1674347 


\title{
Categories and Boundaries in Sámi Exhibitions ${ }^{1}$
}

Nika Potinkara

Department of History and Ethnology, University of Jyväskylä, Finland

\begin{abstract}
This article examines the construction of ethnicity in the permanent exhibitions of two Sámi museums: Siida, the National Museum of the Finnish Sámi and a Nature Centre of Metsähallitus, and Ájtte, the Swedish Mountain and Sámi Museum. The aim of the article is to find out how ethnic categories and boundaries are created by the exhibitions, and how the museum presentations relate to contemporary public discussions about Sámi ethnicity. The presentations are analysed within the framework of discourse analysis. The findings suggest that the two museums, with a few possible exceptions, tend to produce a clear and stable ethnic boundary between the Sámi and other ethnicities. Like the Sámi ethnopolitical movement, the exhibitions emphasize the unity and togetherness of the Sámi people rather than cultural or social heterogeneity within Sámi societies.
\end{abstract}

\section{KEY WORDS}

ethnicity, museum exhibitions, the Sámi, discourse analysis

\section{Introduction}

'The Sámi' as an ethnic category refers to a heterogeneous, multilingual population that has traditionally lived in parts of Norway, Sweden, Finland and Russia. In the past, the status of the Sámi was often low compared to that of the majority populations - the Norwegian state in particular aimed to assimilate the Sámi into the Norwegian majority, and Sámi ethnicity was more or less stigmatized in the other countries as well (Lehtola 1997, 44; Åhrén 2008). During recent decades this stigmatization has diminished, and since the Sámi are now generally perceived as an indigenous people with a special and valuable culture, Sámi status may even be a form of symbolic capital for an individual (see Valkonen, S. 2009).

International treaties and declarations such as the Indigenous and Tribal Peoples Convention of the International Labour Organization (ILO 169) have brought the rights of indigenous peoples into public discussion. While the ILO 169 Convention has not been ratified by Sweden or Finland, the ratification and its possible legal consequences have for long been an important talking point in the traditional Sámi areas of northern Finland and Sweden. Especially in Finland, this has led to a situation where the possession of Sámi identity has become popular, with some individuals claiming to be Sámi but not being generally accepted by the Sámi community (see Valkonen, J. et al. 2017). A controversy has arisen over what it means to be a Sámi and who is entitled to such an identity.

Sámi ethnicity can also be problematic for persons whose ethnic self-identification is not openly questioned or disputed. People living outside the traditional Sámi areas or not speaking a Sámi language sometimes feel inferior to other Sámis who are perceived as more authentic or genuine (see Gaski 2000; Valkonen, S. 2009). Some informants in previous research have used special terms such as 'Super Sámi' to describe people who are 'Sámi enough' or more Sámi than others (Åhrén 2008, 159). The category of the Sámi is thus not merely something a person can either belong or not belong to; at least on certain occasions, people classified as Sámi may be considered by the community as better or worse representatives of this category. 
Who, then, decides what it takes to be a Sámi? In Norway, Sweden and Finland, the Sámi have limited self-government with Sámi parliaments, and some criteria ${ }^{2}$ have been established in order to define who has the right to vote in their elections. In addition to this official macro-level definition, ethnicity is constantly constructed on the micro level; the categorization by ordinary people in everyday interaction may differ substantially from official categories (Brubaker et al. 2004, 35). Between the macro and micro levels, there are median level actors such as various organisations that mobilize groups for diverse purposes. According to the anthropologist Fredrik Barth $(2000,21)$, it is on the median level that stereotypes are established and collectivities are set in motion.

Museums, too, can be seen as actors contributing to ethnic categorization processes between the micro and macro levels. As museums are expected to convey reliable information (Knell 2011, 4), they have more authority than many other actors. In contemporary post-colonial discourse, where the representations of minorities and indigenous peoples by Western majorities have been heavily criticized, self-representations by minority members themselves are often seen as more accurate and authentic than outsiders' accounts. Nordic Sámi museums, created and governed at least partly by the Sámi themselves, may thus be considered to present a doubly authoritative account of Sámi ethnicity: they have the reliability that museums in general possess, and they are also assumed to represent an 'insider's view'.

This article explores the ethnicity constructed by the permanent exhibitions of two Sámi museums, Siida in Finland and Ajtte in Sweden. What kind of ethnic categories and boundaries do the exhibitions create? Museum presentations are examined within the context of the contemporary public discussion about Sámi ethnicity. The aim of the article is thus to ascertain how the two museums, by exhibiting Sámi culture and history, contribute to this discussion.

\section{Theoretical and methodological framework}

Exhibitions of Sámi museums have been previously studied by researchers in different academic fields (e.g. Olsen, B. 2000a; Webb 2006; Levy 2006; Magnusson 2006; Mathisen, S.O. 2014), and attention has also been paid to Sámi exhibitions in other museums (e.g. Olsen, B. 2000b; Mathisen, S.R. 2004c; Silvén 2008; Kalsås 2015). The previous studies have mostly focused on the representations of the Sámi past and discussed these representations in the context of the museum institution. They have examined the ways in which museums produce the Sámi identity, but they have not tended to problematize the ethnic category itself.

In this article, the focus is on the processes of ethnic boundary-making: rather than examining how museums present the history and culture of a certain group, I am interested in how they contribute to the understanding that different ethnic groups exist (see Brubaker 2004). The theoretical framework of the study is based on a constructionist view of ethnicity (e.g. Barth 1969; Jenkins 1997; Eriksen 2002), and the approach is discourse-analytic, seeing meaning as something that is constructed in and through language (Hall 1997).

According to the sociologist Mats Börjesson, a museum exhibition can be approached from three different positions. First, it is possible to ask what the exhibition represents and whether the subject is represented faithfully - is the exhibition authentic and correct in relation to its subject? Second, the exhibition may be seen as a reflection of contemporary needs and political issues; by studying a display about the past, the analyst tries to uncover a hidden truth about the present. Third, the analyst may be interested in what the exhibition does; the exhibition is analysed on the level of discourse. (Börjesson 2005, 193-195.) This article adopts the third position, taking the reality created by the museum exhibitions themselves as the focus of investigation. This means that the processes of designing and producing museum displays as well as the question of their truthfulness fall outside the scope of the study. 
The primary data of the research consist of the different elements of the permanent exhibitions of the two museums as they were during the fieldwork period in 2009-2012. Since the studied exhibitions mostly date back to the 1990's, they do not necessarily match the contemporary intentions of the museums. Temporary exhibitions that both museums present alongside the permanent ones would probably better reflect actual discussions within Sámi communities and the stories that the museums today want to tell; however, as the permanent exhibitions constitute the basis of the museums' presentations and are, during their lifespan, seen by many more visitors than any temporary exhibitions, it is justified to take them as the object of this analysis.

Museum exhibitions consist of many different elements: exhibition spaces and lighting, artefacts, texts, pictures, installations, dioramas, and sounds. These elements work both independently and together to produce meanings (Moser 2010, 23), which means that the analysis has to take the totality of an exhibition into account. In this research, visual and textual analyses were combined. The analyses concentrated on the organisation and design of the exhibitions, on the themes highlighted in them and on the relationships between the different themes. In analysing the exhibition texts, attention was paid to the subjects and objects constructed by them, the categories used, and the ways in which the texts refer to time and place. The analysis deals with the exhibitions' meaning potentials or communicative possibilities; as museums exhibitions are open to various interpretations (Kratz 2011, 29; Börjesson $2005,195)$, it is not possible to provide an 'objective' account of the meanings produced by them.

Secondary data were used in order to contextualise the representations in the studied exhibitions. These secondary data include a variety of broadcasts and other media materials reflecting contemporary discussions and debates about Sámi ethnicity. I also visited exhibitions of Sámi culture in ten other museums in Norway, Sweden, Finland and Russia, and interviewed the museum directors and curators of Siida and Ájtte. The interviews provided background information about the exhibitions and the intentions of the museums.

In the following, I will briefly discuss the history of representation of the Sámi and the emergence of Sámi museums. I will also give a short account of Siida's and Ájtte's permanent exhibitions in general before proceeding to examine the categories and boundaries produced by them.

\section{The establishment of Sámi museums}

Before the modernization processes of the twentieth century, the Sámi were an exotic 'Other' for the European majority populations. They were generally seen as primitive and heathen, racially or culturally inferior, and were therefore despised or even demonized. (E.g. Isaksson 2001; Mathisen, S.R. 2004a; Mathisen, S.R. 2004b.) On the other hand, the Sámi way of life was sometimes admired, too. As a free and innocent people of nature, they served as a European Noble Savage, and their culture interested explorers and collectors. Sami culture was already displayed in several museums in the nineteenth century (Silvén 2008; Mathisen, S.O. 2012).

During recent decades, questions have been raised concerning the Western representations of minorities, non-European peoples and various groups nowadays classified as 'indigenous peoples'. Museum exhibitions dealing with the Sámi, too, have met with criticism from the 1970's onwards. According to critics, Sámi culture has been portrayed in a stereotypical way, focusing on the culture as it was in the sixteenth and seventeenth centuries - without giving it a distant past or a future. (See Levy 2006; Olsen, B. 2000a; Webb 2006.) Along with the presentations in the exhibitions, the collections of Western museums have also been criticised: the past collection of artefacts among the Sámi has been seen as a manifestation of colonialism (Mulk \& Bayliss-Smith 1999, 379). Today most of the artefacts that are considered to constitute the old Sámi cultural heritage are located outside the traditional Sámi area, and many of them belong to the collections of big national museums. 
According to many academics and activists engaged in the postcolonial discussion, the right to manage one's own cultural heritage means the right to one's own past and is a fundamental human right (e.g. Harlin 2008). In this spirit, the Sámi have established their own museums as a way of reclaiming their cultural heritage. A committee appointed by the Nordic Saami Council set criteria for Sámi museums in 1976: the museums should be governed and managed by the Sámi themselves, with Sámi culture as their main subject; they should respect the Sámi tradition, reflect Sámi values and be situated in a Sámi core area (Edbom 2005, 18). In addition to communicating to non-Sámi people, the museums may act as an arena for internal dialogue about the Sámi identity, thereby promoting a positive selfunderstanding (Sara 2002, 51-52). Several Sámi museums have been established during recent decades, most of them located in that part of the traditional Sámi area that nowadays belongs to Norway. In the following, I will focus on the Finnish and Swedish Sámi museums, Siida and Ájtte.

A Sámi museum was first established in the village of Inari in Finland in 1959, when a Sámi association called Sámii Litto began to collect buildings and artefacts. A few years later, the collection was opened to the public as an outdoor museum. This museum was the basis of Siida, a modern Sámi museum that was partly funded by the European Union and opened in 1998. Apart from being a Sámi museum, Siida is also a nature centre of Metsähallitus, a state enterprise administering state-owned areas of land and water in Finland. The Sámi museum and Metsähallitus work together at Siida, and both were involved in designing the permanent exhibitions. There is an introductory exhibition and a main exhibition that is divided into two parts: a culture section, produced by the Sámi museum, and a nature section, produced by Metsähallitus. The current exhibitions date back to 1998, but Siida is planning to renew them in the near future.

In Sweden, the predecessor of the contemporary Sámi museum was a local museum in the village of Jokkmokk displaying a collection of silverware. In the 1980's, the political mobilisation in the Swedish Sámi community had led to plans to establish a Sámi museum; at the same time, there was also a need for an information centre for mountain trekkers. These goals were combined, and Ájtte, the Swedish Mountain and Sámi Museum, was opened in 1989. The exhibitions of Ájtte have been established at different times, the earliest ones dating back to 1989 and the newest being opened in 2014. This article only examines those exhibitions that were on display during the fieldwork period in 2009-2012, which means that the most recent exhibitions are excluded from the research data.

The two museums have much in common in terms of the organization and content of their exhibitions. Apart from the introductory exhibitions, which are partly chronological in both museums, the organization of the exhibitions is thematic. Both museums concentrate on the 'traditional' Sámi culture before the modernization processes of the twentieth century and divide this culture into a few sections such as clothing, handicrafts, and religion. They also display traditional means of livelihood: reindeer herding, fishing, and farming. Among these, the presentations of reindeer herding tend to dominate particularly in Ájtte, where several presentational choices contribute to the notion of the Sámi as mainly reindeer herders (Potinkara 2012). In addition to displaying 'traditional' culture, the museums also make references to modernization and to some contemporary practices, especially in presenting reindeer herding.

The natural environment of the North is on display along with Sámi culture. In Siida, the main exhibition consists of a nature section, focusing on the annual rhythm in the North, and a culture section focusing on Sámi culture. Both parts of the exhibition are located in the same big room, the nature section surrounding the culture section. Parts of the nature section can be seen inside the culture section as well, and natural sounds dominate the soundscape of the space, which permits the natural environment of the North to create a framework for Sámi culture. In Ájtte, several exhibitions about Sámi culture also include presentations of the natural environment; especially an exhibition called Laponia focuses both on the natural and the cultural history of a certain area. Both museums thus associate the Sámi with the 
northern natural environment. Sámi people living outside traditional Sámi areas are not represented or even mentioned in either of the museums.

The content of the exhibitions is thus fairly similar in the two museums. However, the narrative styles differ. In Siida, the style of the exhibition texts is scholarly and formal: the exhibitions look at Sámi culture from the outside and attempt to present an 'objective' view of the culture. No reference is made to the thoughts or experiences of individuals. In Ájtte, the tone in the texts is often more personal, and the pronoun 'we' is widely used, creating a sense of an insider's view. Individuals - both historical and fictional persons - are foregrounded in some of the exhibitions.

\section{One people?}

During the twentieth century, and especially from the 1960's onwards, there was a political mobilisation among the Sámi. Ethno-political activists portrayed the Sámi as a people and a nation, and this selfunderstanding gradually spread to a larger Sámi population (see e.g. Eidheim 1997; Lantto \& Mörkenstam 2008; Lehtola \& Länsman 2012). According to this new understanding, the Sámi living in different countries constitute one people with a shared history, culture, language and heritage. Several national symbols have been established, including a flag, a national day and a national anthem. The Sámi have thus adopted emblems typical of nation-states, even though they are not a politically sovereign nation. An important symbol is the concept of a mythical homeland, Sápmi - the traditional Sámi area that nowadays belongs to Norway, Sweden, Finland, and Russia.

The process of becoming a people or a nation is represented in the exhibitions of Siida. According to a text in the main exhibition, becoming a unitary people was a consequence of external factors such as colonisation, the attempt to assimilate the Sámi into the dominant cultures, and the fact that their natural environment and means of livelihood had become endangered. In the introductory exhibition there is a timeline that portrays changes in natural and cultural history, beginning with the end of the last Ice Age and ending in the 1990's. In the later part of this timeline, photographs and captions refer to several events and mileposts related to the rise of the Sámi ethno-political movement. There is no similar narrative to be found in the exhibitions of Ájtte.

Both museums portray the Sámi as one people, comparable to other peoples of the world. In a way, the sheer existence of Siida and Ájtte as Sámi museums contributes to the understanding of the Sámi as a people with its own history and culture. On the other hand, the existence of separate museums for Finnish and Swedish Sámi somewhat paradoxically highlights the significance of nation-states. This is reflected in the content of the exhibitions as well.

In Siida, several references are made to Sámi living in different countries, but especially in the main exhibition, the weight is clearly on the history and culture of Finnish Sámi. In Ájtte, representations of Sámi identities or experiences outside Swedish Sápmi are almost non-existent. There are some small drawings depicting traditional Sámi costumes across the whole transnational Sámi area, but costumes of the Swedish Sámi are given much more attention than others: they are also exhibited in the form of actual garments, worn by mannequins in large showcases. The people represented in Ájtte's exhibitions are not explicitly defined in terms of nationality or place of residence, but when references are made to specific places or occasions, they always relate to the Swedish Sámi area. Siida thus mainly presents the Finnish Sámi whereas Ájtte almost entirely focuses on the Swedish Sámi. The Sámi living on the coast of Norway, for example, are not depicted in either of the museums.

The implicit emphasis on nation-states is also noticeable in the maps exhibited in Siida. Whereas the maps in Átte are without national borders, the majority of the numerous maps in the culture section of Siida's main exhibition not only show these borders but also highlight the area of Finland by depicting it in a darker colour than other areas (Picture 1). The museum represents, perhaps unintentionally, the 
world as consisting primarily of separate states and thus contributes to 'banal nationalism' (Billig 1995). Instead of applying the concept of a transnational Sápmi, as introduced and promoted by the Sámi ethno-political movement and illustrated in many special maps since 1975 (Conrad 2004), Siida visually highlights the Finnish nation-state. The hegemony of the state is further reproduced by using Finnish place names in the map. ${ }^{3}$

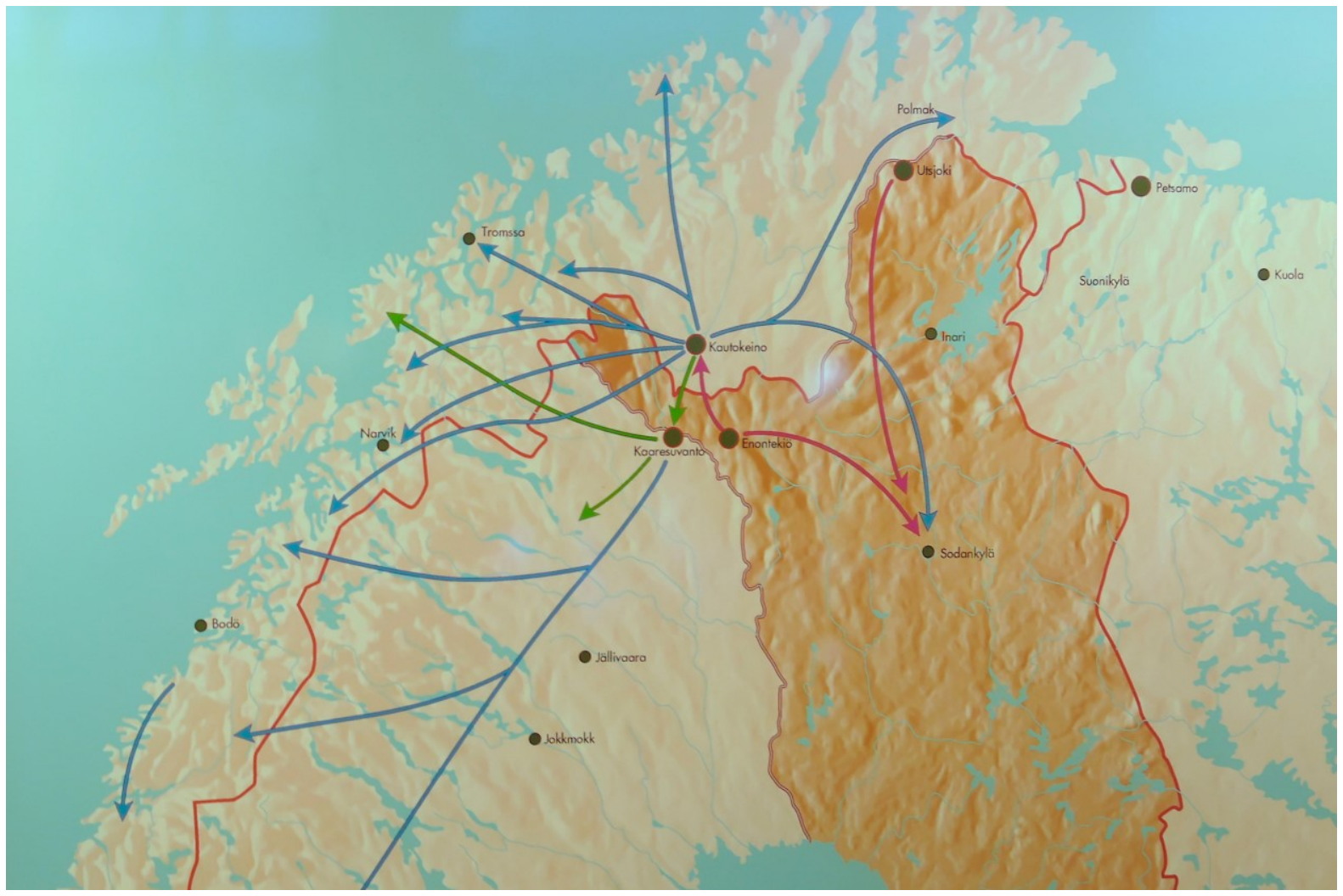

Picture 1: A map depicting migration in the main exhibition of Siida

Even though the Sámi ethno-political movement has constructed an image of one, united Sámi nation, references are commonly made to different Sámi groups, as the Sámi have traditionally been divided into smaller ethnicities, mainly on linguistic grounds. In Finland, for example, there are three different Sámi languages: North Sámi, Aanaar or Inari Sámi, and Skolt Sámi, with North Sámi having significantly more speakers than the two other languages. The linguistic categories are sometimes connected to categories based on means of livelihood - in Finland, the nomadic reindeer herders of the past can be linked to a North Sámi ethnicity - or to different traditional territories. However, these different grouping systems may not always coincide with each other (Lehtola 1997, 8).

Sámi sub-categories are mentioned in the exhibitions of Siida. The introductory exhibition presents a map of the traditional areas of different Sámi languages, and numerous texts in the main exhibition refer to ethnic sub-categories. One category, the Skolt Sámi, is explicitly depicted as a culturally and historically distinct group - an internal minority among the Finnish Sámi. One of the 11 themes in the main exhibition's culture section focuses on them, and they are also discussed separately in some other themes of the main exhibition: for example, the section that focuses on fishing and farming contains a text about Skolt Sámi fishing, while other texts in this section describe fishing practices without reference to ethnic sub-groups. It is thus possible to interpret the main exhibition of Siida as dividing 
the Sámi, on the level of the organization of the display, into two different categories: the (Finnish) Sámi in general, and the Skolt Sámi with their special history and culture.

In Ájtte, different Sámi groups are hardly mentioned in the texts. The pronoun 'we', which most of the exhibitions frequently use to refer to people both of the distant past and of the present day, creates a sense of a unitary nation. Relationships between Sámi groups or interaction and power relations within Sámi societies are not discussed in either of the museums.

\section{Neighbours, exploiters and relatives}

Sámi people constitute a minority in all the countries they live in, and very often they are a minority at the local level, too; in Finland, for example, there is only one municipality where the Sámi constitute a majority of the population. The area traditionally inhabited by the Sámi has been more or less multiethnic in the past as well. This ethnic heterogeneity tends not to be represented in the exhibitions of Sámi museums, with the exception of the Sámi museum in Lovozero, Russia, where the exhibition depicts both Sámi and Komi culture and also contains many references to the history of Russians and Nenets in the Kola Peninsula. ${ }^{4}$ In the Nordic Sámi museums that I visited during the fieldwork period, ${ }^{5}$ the Sámi are generally portrayed as a separate entity.

However, the exhibitions of Siida and Ájtte sometimes refer to the ethnic diversity of the North: for example, there are inhabitant statistics in Siida's introductory exhibition, giving the number of Sámi and Finnish inhabitants in three municipalities in northern Finland at different times. In Ájtte, one of the permanent exhibitions is about the life of an ethnically diverse group, the settlers, around 1900 in the Swedish Sámi area. The main text of this exhibition mentions that the settlers were Sámi, Swedes and Finns and that they learned from each other and intermarried, thus developing a mixed culture. There are interesting differences between this exhibition and other exhibitions in Ájtte; the most striking fact is that the pronoun 'we', which is used in Ájtte's other exhibitions, is not used in the texts of the settler exhibition. This can be interpreted as excluding the ethnically mixed settlers of the past from the Sámi heritage (Potinkara 2012). In addition to this display, it is also possible to interpret Ájtte's introductory exhibition as reflecting ethnic heterogeneity. In this exhibition, the local past is displayed through ten almost natural-size human figures, representing different generations and means of livelihood. Some of the figures - the settler, the railway worker and the logger - bear no obvious signs of Sáminess and represent ways of life that are generally not associated with the Sámi.

Both museums make several references to cultural influences from other peoples and to trade relations between the Sámi and others. In describing these cultural contacts, the exhibition texts use non-Sámi ethnic categories such as 'neighbouring peoples'. In Ájtte, some of the exhibitions previously also mentioned 'strangers', referring to people who came from elsewhere and exploited the local population. A diorama and some texts describing these strangers were part of the exhibitions when I began my fieldwork in 2009, but they had been removed by the time of my last fieldwork visit in $2012 .{ }^{6}$ The diorama and texts about exploiting strangers were probably the most significant representation of colonialism in the exhibitions. Even after their removal, colonialism or colonisation is a theme that both museums address in their exhibitions. Especially the Christianization of the Sámi is represented as a process of oppression in Ájtte.

Neither of the museums explicitly refers to the interaction between the Sámi and other people today. Trade relations, cultural influences, and - in the case of Ájtte - ethnically heterogeneous communities are explicitly discussed only in representing the past. The museums also conceptually separate the Sámi from others in depicting the past: 'neighbouring peoples' are not represented as being related to the Sámi, ${ }^{7}$ and even though the Sámi may have had various kinds of interaction with them, they are not seen as belonging together. 
Instead, the museums construct a connection between the Sámi and other groups that are today generally classified as indigenous peoples. The introductory exhibitions of both museums contain a map of the northern hemisphere or of a more restricted northern area, and in both cases there are names of various peoples linked to the maps (Picture 2). In Siida, these are defined as 'circumpolar peoples', whereas there is no explicit definition in Ájtte. An accompanying text in Ájtte, however, refers to the rights of indigenous peoples. Majority populations such as Finns or Swedes are not marked on these maps, even though they too live in the depicted areas. The maps thus disconnect the Sámi from the ethnic majorities living near or among them and instead construct an affinity between the Sámi and other smaller ethnicities, regardless of the geographical distance between their habitats. 

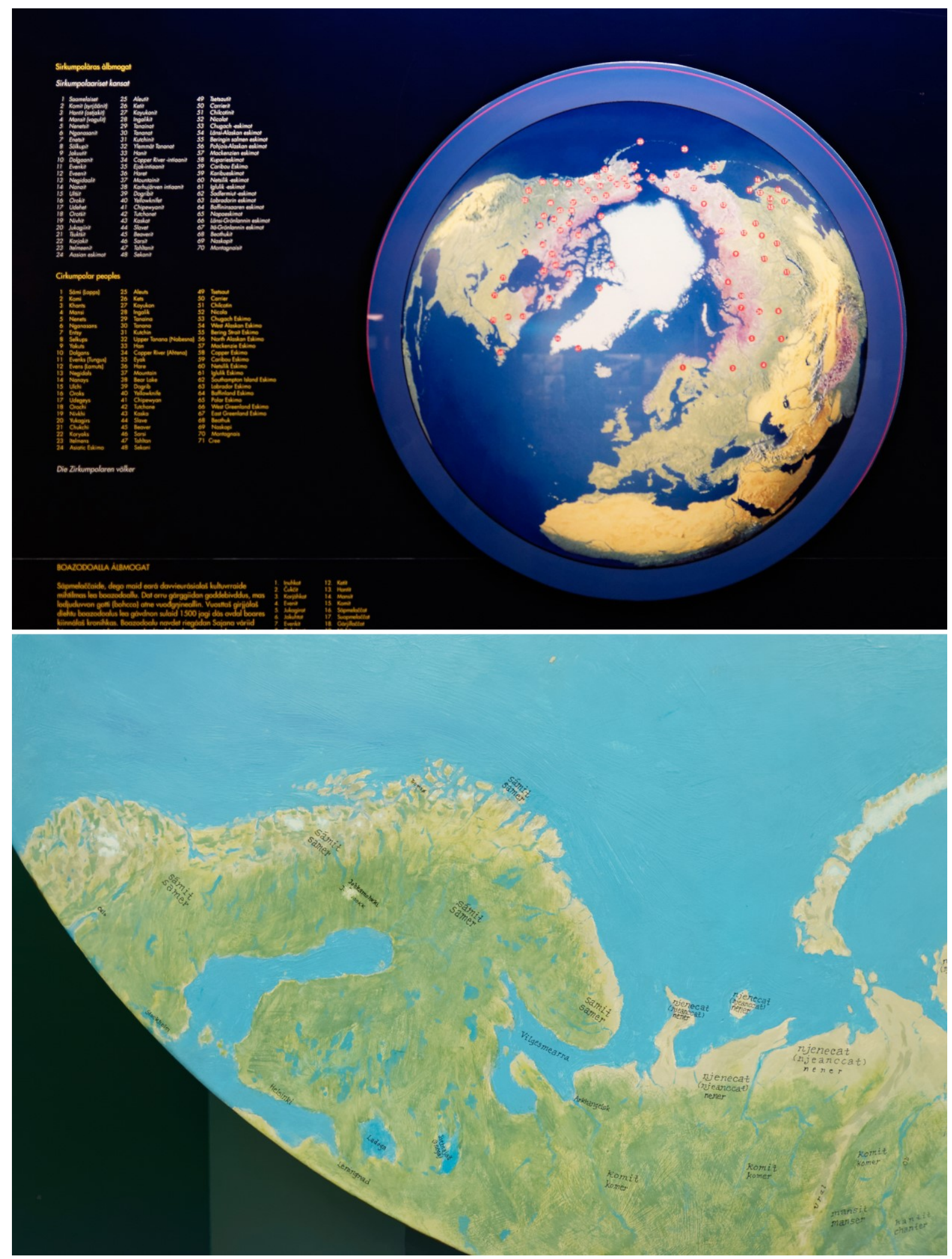

Picture 2: A map of circumpolar peoples in the introductory exhibition of Siida and a detail of a map in the introductory exhibition of Ájtte

The indigeneity of the Sámi and their relation to other indigenous peoples has been a central theme in Sámi ethno-politics (see Eidheim 1997, 36-37; Valkonen, S. 2009, 137-210; Nyyssönen 2007). Ever 
since the 1970's, Sámi activists have begun to find parallels between their situation and that of other indigenous peoples, and they have also participated actively in the international indigenous movement. Today the indigeneity of the Sámi is widely recognized, also at the governmental level. Indigeneity is mentioned in some exhibition texts in Siida and Ájtte, but compared to the emphasis that this concept has had in Sámi ethno-politics, both museums make relatively few references to indigenous peoples. In the above-mentioned maps the museums only represent northern peoples, whereas the Sámi exhibition of the Nordic Museum in Stockholm displays portraits of individuals representing different indigenous peoples, some of them from the southern hemisphere, and thus connects the Sámi with indigenous peoples worldwide. ${ }^{8}$

\section{Ambiguous ethnicity?}

As noted in the previous section, Sámi areas are and have been ethnically heterogeneous. Mixed marriages have not been uncommon, which means that in addition to people with a completely Sámi background, there are many individuals who are descendants of both Sámi and people classified as members of other ethnicities. Furthermore, persons who are descendants of members of one ethnic category may have adapted cultural features that are associated with another category, and this may have led to a situation where their ethnicity has become ambiguous (Lehtola 2012, 41). While many individuals with Sámi ancestry today unproblematically identify themselves as Sámi, others are unsure about their ethnicity or see themselves as both Sámi and something else (see Olofsson 2004; Valkonen, S. 2009, 261-269). Is this multiple, ambiguous, or unclear ethnicity represented in the permanent exhibitions of Siida and Ájtte?

There are a couple of references to the crossing of ethnic boundaries in Siida's main exhibition: according to the exhibition texts, the indigenous Sámi population of the Sodankylä region had assimilated into Finnish settlers by the beginning of the eighteenth century, and the texts also mention some cultural features that the Sámi have adapted from other ethnic groups. The crossing of an ethnic boundary, however, does not mean that the boundary itself had become blurred, and there are no references to hybrid or ambiguous ethnicity at the individual level in Siida's permanent exhibitions. The population statistics from three municipalities, presented in the introductory exhibition, implicitly portray ethnic boundaries as unproblematic at the individual level: in these statistics, each individual is classified either as a Finn or as a Sámi.

In Ájtte, there is, as mentioned above, an exhibition about an ethnically heterogeneous group of settlers. The settlers are not personified in the exhibition space, but according to a guide booklet, the exhibition is about the life of a family with a Sámi mother and grandmother. The ethnicity of other family members is not defined, so it is up to the visitor to decide whether they are Swedes, Finns or perhaps multi-ethnic. As in Siida, the ethnic boundary is crossed - here by a mixed marriage - but there are no explicit references to the potential fuzziness of the boundary itself.

However, one of Ájtte's exhibitions, dating back to 1997, does bring up issues that are related to ethnic ambiguity. In a section that presents Sámi costumes ${ }^{9}$ across the Swedish Sámi area, there is a short citation - with no information about its origin - accompanying each showcase. The text that is linked to a showcase about the Jokkmokk area says: 'I dressed in a Sámi costume for the first time last summer. But I felt vulnerable in the costume, as I could not speak Sámi.' ${ }^{10}$ This can be interpreted as referring to unclear ethnicity or to problems in identifying oneself as a Sámi: by dressing in a traditional Sámi costume, the unknown speaker conveys the fact that they identify themself as a Sámi, but at the same time appears to feel not Sámi enough.

It is possible to see hints about the fuzziness of the ethnic boundary in some other texts in this section, too. In one text, an anonymous speaker says that making a Sámi costume feels like a good thing to do, and at the same time, 'one sighs heavily' ${ }^{11}$. When viewed against the history of Sámi assimilation, this 
can be interpreted as implying that Sámi ethnicity may be disappearing. Also some other texts that highlight the significance of Sámi costumes for the Sámi identity may be interpreted as implicitly revealing the potential fragility of Sámi ethnicity. The theme is only discussed indirectly, through these anonymous citations; the other exhibition texts do not mention it.

Thus the possibility of an individual's ambiguous ethnic identity is a theme that is not discussed in Siida, and in Ájtte, it is represented as something negative - as vulnerability. There are no references to multi-ethnic identity as a strength in either of the museums. In this respect, they differ from the Sámi exhibition of the Nordic Museum in Stockholm, where the possibility of a double identity is mentioned as a potential resource for an individual.

\section{Conclusions}

In this article I have discussed some ways in which two Sámi museums, Siida and Ájtte, present the Sámi in their permanent exhibitions. As institutions focusing on the Sámi and their special heritage, the museums create an ostensibly natural ethnic boundary between the Sámi and other ethnicities. In Siida, ethnic boundaries are also constructed within the category of the Sámi, and the Skolt Sámi are presented separately as a special minority group. No such clear distinctions can be found in Ájtte.

The boundary between the Sámi and other ethnicities appears to be clear and stable, especially in Siida: some people unequivocally belong to the category of the Sámi while others do not. Also in Ájtte, the exhibitions in general do not imply that a person's ethnic identity could be vague, hybrid, multi-ethnic, or contested. Some quotations in Ájtte's costume exhibition, however, refer to the possible fragility of a person's ethnic identity and thus make the ethnic boundary somewhat blurred.

With the exception of Ájtte's settler exhibition, in which the ethnic boundaries are not congruent with the cultural ones, the museums contribute to the perception of the Sámi as a separate entity. Both museums describe relations between the Sámi and other ethnicities and make a connection between the Sámi and other northern peoples today labelled as indigenous, thus highlighting the similarities and togetherness of these peoples regardless of the geographical distance between their habitats. At the same time, however, in representing Sámi culture and history both museums focus on the Sámi population in the areas of their respective nation-states - Finland in the case of Siida and Sweden in Ájtte. This weakens the image of a single unified Sámi people that the museums otherwise promote.

The construction of Sámi ethnicity in the exhibitions of Siida and Ájtte resembles the images produced by the Sámi movement. When this movement grew up, Sámi ethnicity was weaker and more stigmatized than it is today. In the ethno-political struggle for rights and recognition, the unity and togetherness of the Sámi people were emphasized, and often there was little room to delve into internal differences (Stordahl 1996, 95). Unifying symbols such as reindeer herding are still widely used, and power relations within Sámi communities (see Amft 2000, 116, 192; Valkonen, S. 2009, 247-249) are seldom mentioned in the ethno-political discourse. The ethnic boundary is generally highlighted at the expense of cultural or social heterogeneity within it.

As contemporary Sámi museums contribute to this boundary-making, their role bears a resemblance to the role that Western national museums played in the nineteenth century by portraying peoples as natural entities and constructing pasts that served to legitimate political goals (see Graham et at. 2005, 27; Aronsson 2010; Aronsson 2011; Olsen, K. 2000). Today, some of these institutions may support postmodern notions of identity or highlight heterogeneity and pluralism within the nation (see Nederveen Pieterse 2005; Levitt 2015; Aronsson 2010, 352). Essentialism is no longer fully accepted in the portrayal of established Western nations - or at least it is not as overt as in the past. Representations of minorities, on the other hand, still often tend to essentialize and present uniformity. 
Sámi museums are intended to promote a positive Sámi self-understanding and strengthen the Sámi identity (Sara 2002). In order to construct an ethnic identity, they have to base their presentations on some generally accepted ethnic markers such as the northern Sámi area or reindeer herding. The more tightly museums connect Sáminess to generally known markers, the more recognizable an ethnicity they create. Discussing internal diversities and controversies, multi-ethnic identities or problems in selfidentification would result in a less clear image of what it means to be a Sámi. However, by concentrating on unity museums may exclude experiences of some Sámi individuals and contribute to internal hierarchies and hegemonies within Sámi communities.

\footnotetext{
${ }^{1}$ The article is based on the author's doctoral dissertation that was published in Finnish (Potinkara 2015). The work was funded by the University of Jyväskylä and several foundations, including Alfred Kordelin Foundation, Emil Aaltonen Foundation, Finnish Cultural Foundation, Nordenskiöld-samfundet, and Finnish Concordia Fund. ${ }^{2}$ The official definitions are mostly based on the language that has been spoken in one's home or in the home of one's parents or grandparents. In Finland, entries in old population registers are also mentioned as possible criteria. ${ }^{3}$ Four languages - North Sámi, Finnish, English and German - are used in Siida's exhibition texts, and some maps in the culture exhibition use all of them, while others only use Finnish names (cf. Kelly-Holmes \& Pietikäinen 2016, 33).

${ }^{4}$ I visited the museum in Lovozero in 2008 and 2009.

${ }^{5}$ Besides Siida and Ájtte, I visited the Sámi museums in Karasjok and Varangerbotn in 2008.

${ }^{6}$ According to the museum director of Ájtte, the diorama was removed because it was not consistent with the contemporary understanding of the past (interview with Kjell-Åke Aronsson, December 4, 2012). However, it was later included - in a slightly altered form - in a new exhibition that opened in 2014 (personal communication with Kjell-Åke Aronsson, October 5, 2015).

${ }^{7}$ The Sámi languages, on the other hand, are portrayed as being related to the Finnish, Estonian and Karelian languages in a language tree in Siida's introductory exhibition.

8 I visited the Nordic Museum's Sámi exhibition in 2010.

${ }^{9}$ In the past, traditional Sámi costumes were worn in everyday life, but nowadays they are mainly used on special occasions such as weddings or festivals. The costumes function as ethnic markers since non-Sámi individuals are not expected to wear them.

${ }^{10}$ My translation of the Swedish text: 'Jag klädde mig i kolt första gången förra sommaren. Men jag kände mig skör i kolt, när jag inte kunde tala samiska.'

${ }^{11}$ My translation of the Swedish text: 'Det känns som en god gärning varje gång jag syr en kolt. Samtidigt som man suckar tungt.'
}

\section{References}

Amft, Andrea. 2000. Sápmi i förändringens tid: En studie av svenska samers levnadsvillkor under 1900talet ur ett genus- och etnicitetsperspektiv. Umeå: Umeå universitet.

Aronsson, Peter. 2010. "Europeiska nationalmuseer som förhandlingsarenor.” In Samling og museum: Kapitler av museenes historie, praksis og ideologi, edited by Bjarne Rogan and Arne Bugge Amundsen, 341-358. Oslo: Novus forlag.

Aronsson, Peter. 2011. "Explaining national museums: Exploring comparative approaches to the study of national museums." In National Museums: New Studies from Around the World, edited by Simon J. Knell et al., 29-54. London and New York: Routledge.

Barth, Fredrik. 1969. "Introduction." In Ethnic Groups and Boundaries: The Social Organization of Culture Difference, edited by Fredrik Barth, 9-38. Oslo: Universitetsforlaget. 
Barth, Fredrik. 2000. "Enduring and emerging issues in the analysis of ethnicity." In The Anthropology of Ethnicity: Beyond 'Ethnic Groups and Boundaries', edited by Hans Vermeulen and Cora Govers, 11-32. Amsterdam: Het Spinhuis.

Billig, Michael. 1995. Banal Nationalism. London, Thousand Oaks and New Delhi: Sage Publications. Brubaker, Rogers. 2004. Ethnicity without Groups. Cambridge and London: Harvard University Press. Brubaker, Rogers, Mara Loveman and Peter Stamatov. 2004. "Ethnicity as Cognition." Theory \& Society 33: 31-64.

Börjesson, Mats. 2005. "Vad gör en museiutställning? Om social kategorisering, historiens framsteg och museernas nya roll." RIG-Kulturhistorisk tidskrift 88, no. 4: 193-209.

Conrad, Joann. 2004. "Mapping Space, Claiming Place: The (Ethno-) Politics of Everyday Geography in Northern Norway." In Creating Diversities: Folklore, Religion and the Politics of Heritage, edited by Anna-Leena Siikala, Barbro Klein and Stein R. Mathisen, 165-189. Helsinki: Finnish Literature Society.

Edbom, Gunilla. 2005. Samiskt kulturarv i samlingar: Rapport från ett projekt om återföringsfrågor gällande samiska föremål. Sametinget \& Ájtte.

Eidheim, Harald. 1997. "Ethnopolitical Development among the Sami after World War II." In Sami Culture in a New Era: The Norwegian Sami Experience, edited by Harald Gaski, 29-61. Karasjok: Davvi Girgi OS.

Eriksen, Thomas Hylland. (1993) 2002. Ethnicity and Nationalism: Anthropological Perspectives. Second Edition. London and Ann Arbor: Pluto Press.

Gaski, Lina. 2000. "Hundre prosent lapp?” Lokale diskurser om etnisitet i markebygdene i Evenes og Skånland. Kautokeino: Sámi Instituhtta.

Graham, Brian, Gregory John Asworth, and John E. Tunbridge. 2005. "The uses and abuses of heritage." In Heritage, Museums and Galleries: An Introductory Reader, edited by Gerald Corsane, 26-37. London and New York: Routledge.

Hall, Stuart. 1997. "The work of representation." In Representation: Cultural Representations and Signifying Practices, edited by Stuart Hall, 13-74. London, Thousand Oaks and New Delhi: Sage Publications.

Harlin, Eeva-Kristiina. 2008. "Repatriation as Knowledge Sharing - Returning the Sámi Cultural Heritage." In Utimut: Past Heritage - Future Partnerships: Discussions on Repatriation in the $21^{\text {st }}$ Century, edited by Mille Gabriel and Jens Dahl, 192-201. Copenhagen: IWGIA/NKA.

Isaksson, Pekka. 2001. Kumma kuvajainen: Rasismi rotututkimuksessa, rotuteorioiden saamelaiset ja suomalainen fyysinen antropologia. Kustannus-Puntsi.

Jenkins, Richard. 1997. Rethinking Ethnicity: Arguments and Explorations. London, Thousand Oaks and New Delhi: Sage Publications.

Kalsås, Vidar Fagerheim. 2015. "Minority history in museums: Between ethnopolitics and museology." Nordisk Museologi 23, no. 2: 33-48.

Kelly-Holmes, Helen and Sari Pietikäinen. 2016. "Language: A Challenging Resource in a Museum of Sámi Culture." Scandinavian Journal of Hospitality and Tourism 16, no. 1: 24-41. 
Knell, Simon. 2011. "National museums and the national imagination." In National Museums: New Studies from around the World, edited by Simon J. Knell et al., 3-28. London and New York: Routledge.

Kratz, Corinne A. 2011. "Rhetorics of Value: Constituting Worth and Meaning through Cultural Display." Visual Anthropology Review 27, no. 1: 21-48.

Lantto, Patrik and Ulf Mörkenstam. 2008. "Sami Rights and Sami Challenges: The modernization process and the Swedish Sami movement, 1886-2006." Scandinavian Journal of History 33, no. 1: 2651.

Lehtola, Veli-Pekka. 1997. Saamelaiset - historia, yhteiskunta, taide. Kustannus-Puntsi.

Lehtola, Veli-Pekka. 2012. Saamelaiset suomalaiset - kohtaamisia 1896-1953. Helsinki: Suomalaisen Kirjallisuuden Seura.

Lehtola, Veli-Pekka \& Anni-Siiri Länsman. 2012. "Saamelaisliikkeen perintö ja institutionalisoitunut saamelaisuus." In Saamenmaa: Kulttuuritieteellisiä näkökulmia, edited by Veli-Pekka Lehtola, Ulla Piela and Hanna Snellman, 13-35. Helsinki: Suomalaisen Kirjallisuuden Seura.

Levitt, Peggy. 2015. Artifacts and Allegiances: How Museums Put the Nation and the World on Display. University of California Press.

Levy, Janet E. 2006. "Prehistory, Identity, and Archaeological Representation in Nordic Museums." American Anthropologist 108, no. 1: 135-147.

Magnusson, Åse. 2006. "Historien utställd: Samiskt på museum.” In Historieforskning på nya vägar, edited by Klas-Göran Karlsson, Eva Helen Ulvros and Ulf Zander, 45-56. Lund: Nordic Academic Press.

Mathisen, Silje Opdahl. 2012. "Northern Borderlands and the Aesthetics of Ethnicity: Intervisuality and the Representations of the Sami in Early Exhibitions at National Cultural Museums in Norway and Sweden." ARV Nordic Yearbook of Folklore 67: 57-72.

Mathisen, Silje Opdahl. 2014. Etnisitetens estetikk: Visuelle fortellinger og forhandlinger i samiske museumutstillinger. Oslo: Universitetet i Oslo.

Mathisen, Stein R. 2004a. "Ethnic Identities in Global and Local Discourses: Contested Narratives of Sámi Ethnic Heritage." In Cultural Identity in Transition: Contemporary Conditions, Practices and Politics of a Global Phenomenon, edited by Jari Kupiainen, Erkki Sevänen and John A. Stotesbury, 141-157. New Delhi: Atlantic Publishers and Distributors.

Mathisen, Stein R. 2004b. "Hegemonic Representations of Sámi Culture: From Narratives of Noble Savages to Discourses on Ecological Sámi." In Creating Diversities: Folklore, Religion and the Politics of Heritage, edited by Anna-Leena Siikala, Barbro Klein and Stein R. Mathisen, 17-30. Helsinki: Finnish Literature Society.

Mathisen, Stein R. 2004c. "Representasjoner av kulturell forskjell." Tidskrift for kulturforskning 3, no. 3: 5-25.

Moser, Stephanie. 2010. "The Devil is in the Detail: Museum Displays and the Creation of Knowledge." Museum Anthropology 33, no. 1: 22-32.

Mulk, Inga-Maria \& Tim Bayliss-Smith. 1999: "The representation of Sámi cultural identity in the cultural landscape of Northern Sweden: The use and misuse of archaeological knowledge." In The Archaeology and Anthropology of Landscape: Shaping your landscape, edited by Peter J. Ucko and Robert Layton, 358-396. London and New York: Routledge. 
Nederveen Pieterse, Jan. 2005. "Multiculturalism and museums: Discourse about others in the age of globalization." In Heritage, Museums and Galleries: An Introductory Reader, edited by Gerald Corsane, 163-183. London and New York: Routledge.

Nyyssönen, Jukka. 2007. "Everybody recognized that we were not white": Sami Identity Politics in Finland, 1945-1990. Tromsø: University of Tromsø.

Olofsson, Ebba. 2004. In Search of a Fulfilling Identity in a Modern World: Narratives of Indigenous Identities in Sweden and Canada. Uppsala: Uppsala University.

Olsen, Bjørnar. 2000a. "Bilder fra fortida? Representasjoner av samisk kultur i samiske museer." Nordisk Museologi 8, no. 2: 13-30.

Olsen, Bjørnar. 2000b. “Sápmi: en nasjon blir til?” Museumsnytt 49, no. 5/6: 20-23.

Olsen, Kjell. 2000. "Ethnicity and Representation in a 'Local' Museum.” In Folklore, Heritage Politics, and Ethnic Diversity, edited by Pertti J. Anttonen, Anna-Leena Siikala, Stein R. Mathisen and Leif Magnusson, 140-157. Botkyrka: Multicultural Centre.

Potinkara, Nika. 2012. "Representing Cultural Difference: Sámi Reindeer Herding as a Signal of Ethnic Boundary in the Exhibitions of Two Sámi Museums." Nordisk Museologi 20, no. 2: 83-96.

Potinkara, Nika. 2015. Etnisyyden rakentuminen kahden saamelaismuseon perusnäyttelyissä. Jyväskylä: Jyväskylän yliopisto.

Sara, Johan Mikkel. 2002. "Samiske museer i samiske samfunn." In Vem äger kulturarvet? Anföranden vid konferens om återföringsfrågor vid Ajtte, Svenskt Fjäll- och samemuseum 6-8 juni 2000, 51-53. Jokkmokk: Ájtte.

Silvén, Eva. 2008. "Staging the Sami: Narrative and Display at the Nordiska Museet in Stockholm." In NaMu IC: Comparing: National Museums, Territories, Nation-Building and Change, edited by Peter Aronsson and Andreas Nyblom, 311-319. Linköping: Linköping University Electronic Press.

Stordahl, Vigdis. 1996. Same i den moderne verden: Endring og kontinuitet i et samisk lokalsamfunn. Karasjok: Davvi Girji.

Valkonen, Sanna. 2009. Poliittinen saamelaisuus. Tampere: Vastapaino.

Valkonen, Jarno, Sanna Valkonen and Timo Koivurova. 2017. "Groupism and the politics of indigeneity: A case study on the Sámi debate in Finland." Ethnicities 17, no. 4: 526-545.

Webb, Sharon Helen. 2006. "Making Museums, Making People: The Representation of the Sámi through Material Culture." Public Archaeology 5, no. 3: 167-183.

Åhrén, Christina. 2008. Är jag en riktig same? En etnologisk studie av unga samers identitetsarbete. Umeå: Umeå universitet. 